\title{
VAISTININKO PADĖJĖJO FARMACINĖS PASLAUGOS ŠIUOLAIKINĖ BŪKLE் VISUOMENĖS VAISTINĖSE LIETUVOJE
}

\author{
EDITA BABONIENE், LAIMUTE் JONAITIENE், ONA RAGAŽINSKIENE் \\ Kauno kolegijos Sveikatos priežiūros fakultetas
}

Raktažodžiai: vaistininkas, vaistininko padèjejjas, farmacinè paslanga, receptiniai vaistai, nereceptiniai vaistai, vaistiniu prekès.

\begin{abstract}
Santrauka
Straipsnyje pateikiama vaistininko padejejo farmacinès paslaugos šiuolaikine būklè visuomenès vaistinèse Lietuvos penkiuose etnografiniuose regionuose. 2012 metais tirtos Aukštaitijos, Žemaitijos, Dzūkijos, Suvalkijos, Mažosios Lietuvos 102 visuomenès vaistinès, kurios yra strategiškai palankiose vaistu pardavimui gyventojams vietose.

$40 \%$ visuomenés vaistiniu dirba tik vienas vaistininko padejejas (farmakotechnikas), o 21,6\% visuomenés vaistiniu - nèra vaistininko padèjejo (farmakotechniko). Gerinant farmacinés paslaugos gyventojams kokybę, racionalu didinti vaistininko padejjeju (farmakotechniku) skaičiu visuomenès vaistinèse.

Vaistiniu tinklams nepriklausomose visuomenès vaistinèse gyventojai perka receptiniu vaistu 36\%, nereceptiniu vaistu - 29,5\%, ekstemporaliu vaistu - 4,4\%, vaistiniu prekiu - 29,7\% . Vaistiniu tinkly vaistinèse gyventojai perka receptiniu vaistu $28 \%$, nereceptiniu vaistu - 25,5\% ir daugiausia (45\%) vaistiniu prekiu.

Tyrimo tikslas: analizuoti vaistininko padejejju (farmakotechniku) farmacine paslauga, vykdant vaistu, vaistiniu prekiu pardavima, nustatant ju iš́davimo dažnį priklausomai nuo vaistiniu statuso. Išryškeje, kad vykdant farmacine paslauga teigiamai ši procesa paveiktu vaistininko padejeju (farmakotechniku) skaičiaus didinimas vaistineje. Didžiausia vaistu ir vaistiniu prekiu apyvartos dali sudaro jevairios vaistiniu prekes, o likusiq apyvartos dali - receptiniai ir nereceptiniai vaistai. Vaistininko padèjeju (farmakotechniku) farmacinès paslaugos nukreipimas pardavineti vaistiniu prekes igalintu vaistininkui skirti daugiau laiko gyventoju konsultavimui ir informavimui sveikatinimo srityje.
\end{abstract}

IVADAS

Vienas iš pagrindinių Lietuvos nacionalinès vaistų politikos tikslų - tinkamos kokybès farmacinès paslaugos teikimas gyventojams. Nacionalinès vaistų politikos nuostatos, apibrěždamos valstybės teisinę, socialinę ir ekonominę raidą farmacijos srityje, numatè ne tik tai, kad turi būti rengiamos ir igyvendinamos valstybès programos, kaip racionaliai, nepažeidžiant asmens ir visuomenės interesų aprūpinti gyventojus tinkamos kokybès, saugiais ir veiksmingais vaistiniais preparatais, bet ir teikti tinkamos kokybès farmacines paslaugas. Dabartiniu laikotarpiu farmacijos sektorius yra vienas iš labiausiai besikeičiančių, dinamiškiausių sektorių sveikatos apsaugos srityje [1]. 2012 m. gegužès 15 d. Lietuvos Respublikos Seimas ypatingos skubos tvarka prièmé Sveikatos reikalų komiteto patobulintą Farmacijos i̊statymo pataisu projektą Nr. XIP-3797(2). Jame numatyta, kad vaistininko padejejjai (farmakotechnikai) vaistinèje teiks sveikatinimo paslaugas, o vaistinès darbo laiku vaistinèje turès dirbti ne mažiau kaip vienas vaistininkas, kuris be savo tiesioginių pareigų prižiūrès ir vaistininko padejjejo (farmakotechniko) teikiamą farmacinę paslaugą, vaistinių preparatų pardavimą (išdavimą), ekstemporalių vaistinių preparatu gamybą. Vaistininko padèjëjo (farmakotechniko) teikiamos farmacinès paslaugos, vaistinių preparatu pardavimo (išdavimo) ir ekstemporalių vaistinių preparatų gamybos priežiūra vaistinèje suprantama kaip receptų, pagal kuriuos vaistininko padejjejjas (farmakotechnikas) pardavè (išdavė) vaistinius preparatus, patikrinimas, jeigu reikia, vaistininko padējëjo (farmakotechniko) konsultavimas (žodžiu ar ryšio priemonėmis), parenkant gyventojui reikalingus vaistinius preparatus, teikiant farmacinę informaciją, vaistininko padejejejo (farmakotechniko) pagamintų ekstemporalių vaistinių preparatų patikrinimas [2]

Tyrimo tikslas: išanalizuoti vaistininko padejëjų (farmakotechnikų) farmacinę paslaugą, vykdant vaistų, vaistiniu prekių pardavimą, nustatant jų išdavimo dažnị priklausomai nuo vaistinių statuso.

\section{TYRIMO METODOLOGIJA}

Tyrimas atliktas 2012 metais vasario - liepos mènesiais Lietuvos penkių etnografinių regionų (Aukštaitijos, Žemai- 
tijos, Dzūkijos, Suvalkijos, Mažosios Lietuvos) visuomenès vaistinèse, naudojant mokslinès literatūros analizès ir anketinès apklausos metodus. I 102 anketų klausimus atsakè vaistiniu tinklu ir nepriklausomų vaistinių darbuotojai. Anketose nurodyta atsakyti ị klausimus apie dirbančiu vaistininku ir vaistininku padèjèju (farmakotechniku) skaičiu, gyventoju, perkančiu vaistinèje receptinius, nereceptinius vaistus bei vaistinių prekes, pirkinių skaičių. Anketų duomenys susisteminti, išanalizuoti panaudojant statistinę duomenų analizę, naudojant SPSS 13 kompiuterinę programą ir pateikti grafiškai. Tyrimo duomenys pateikti absoliučiais skaičiais ir procentais $(\mathrm{p}<0,05)$.

\section{REZULTATAI IR JU APTARIMAS}

Vaistininko padèjèjo (farmakotechniko) farmacinès paslaugos šiuolaikinè būklè Lietuvos penkių etnografinių regionų visuomenès vaistinėse. Farmacinès paslaugos teikimas ir pacientų konsultavimas yra privaloma vaistų išdavimo procedūros dalis ir farmacijos specialisto išskirtinumo garantas. Lietuvos vaistininkų sajungos vadovų nuomone, farmacinè paslauga savo turiniu apima vaistininko sukurtą intelektini produktą - vaisto paskyrimo (recepto) įvertinimą - perdavimą pacientui (klientui). Su šiuo ịvertinimu asmuo, kreipęsis ị vaistininką, gauna kompetentingą informaciją apie vaistą, jo vartojimo būdus, galimus papildomus vaistinius preparatus, naudojamus savigydos principu, mitybos, higienos reikalavimus, naudojant paskirtą vaistą, reikalingus perspejjimus ir kt. [3]. Farmacinè paslauga vaistinejje atliekama pagal "Geros vaistinių praktikos" nuostatas, gali peraugti i farmacinę rūpybą. Tai kompleksinis farmacinès rūpybos paslaugų teikimas, kuri sudaro gyventojų sveikatos duomenų rinkimas, jų kaupimas ir tinkamas

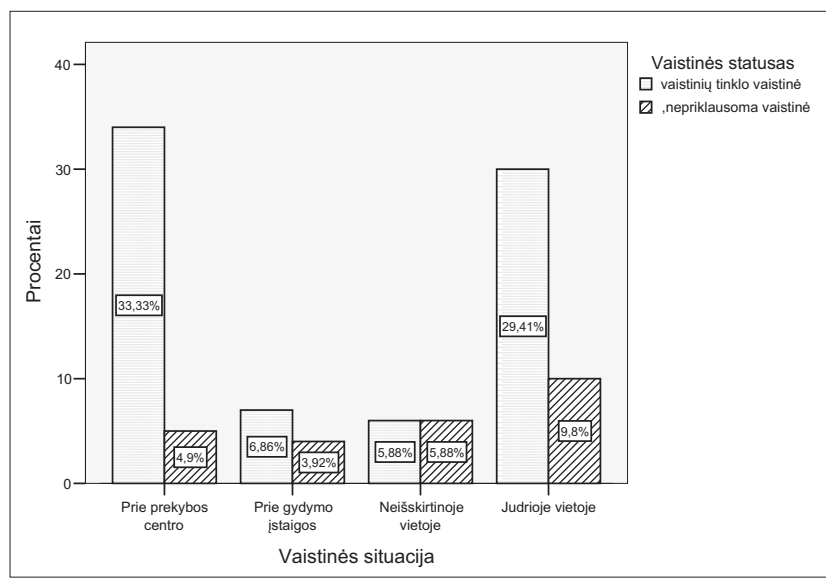

1 pav. Nepriklausomų vaistinių ir vaistinių tinklo vaistinių situacija palankiose vaistu pardavimui vietose penkiuose Lietuvos etnografiniuose regionuose $\left(\chi^{2}-7,935,1 l s-3, p-0,047\right)$ saugojimas bei analizè ir tinkamas įvertinimas, gydymo vaistiniais preparatais plano sudarymas ir realizavimas, gydymo vaistiniais preparatais plano vykdymo priežiūra, modifikacijos bei numatytų rezultatu siekimas. Farmacinès rūpybos paslaugą gali teikti tik sveikatos apsaugos ministro nustatyta tvarka ịvertintos vaistinès ir farmacinès rūpybos tobulinimo kursą išklausę vaistininkai [4]. Vaistinèse turi būti igyvendinti farmacinès rūpybos elementai, išspresti su jais susije ekonominiai, teisiniai, materialinio aprūpinimo klausimai, išugdyti žmogiškieji resursai. Farmacijos specialistų požiūrị i farmacinès paslaugos kokybę visuomenès vaistinėse, vaistininku rengima teikti farmacinès rūpybos paslaugą Lietuvoje nagrinèja eilè autorių [5-9]. Tyrimais nustatyta, kad dalị vaistininko pareigų galima skirti vaistininko padejejui (farmakotechnikui), kuris rengiamas pagal patvirtintus standartus, reglamentuojančius šiam specialistui būtinas kompetencijas [10-15].

Iš 102 tirtu vaistiniu, 77 priklauso vaistinių tinklams, o 25 - nepriklausomos vaistinès. $60 \%$ vaistinių yra Aukštaitijos regione, kuriam priklauso du didieji Lietuvos miestai Vilnius ir Kaunas; 14\% - Dzūkijoje; 11\% - Žemaitijoje; 8\% - Suvalkijoje; 7\% - Mažojoje Lietuvoje. Tirtose vaistinèse dirba 192 vaistininko padejjejjai ir 269 vaistininkai, vienam vaistininkui tenka 0,7 vaistininko padejejo, 20-yje - ju nèra. Valstybinès vaistų kontrolès tarnybos duomenimis, 2011 metu ataskaitoje farmacijos sektoriuje dirbo 4716 farmacijos specialistu, vienam vaistininkui teko 0,59 vaistininko padėjëjo [16] (1 pav.).

Vaistiniu tinklams priklausančios vaistinès dažniau nei nepriklausomos vaistinès yra ịsikūrusios strategiškai palankesnèse gyventojų aptarnavimui vietose - prie prekybos centrų ar judriose miestų vietose (2 pav.).

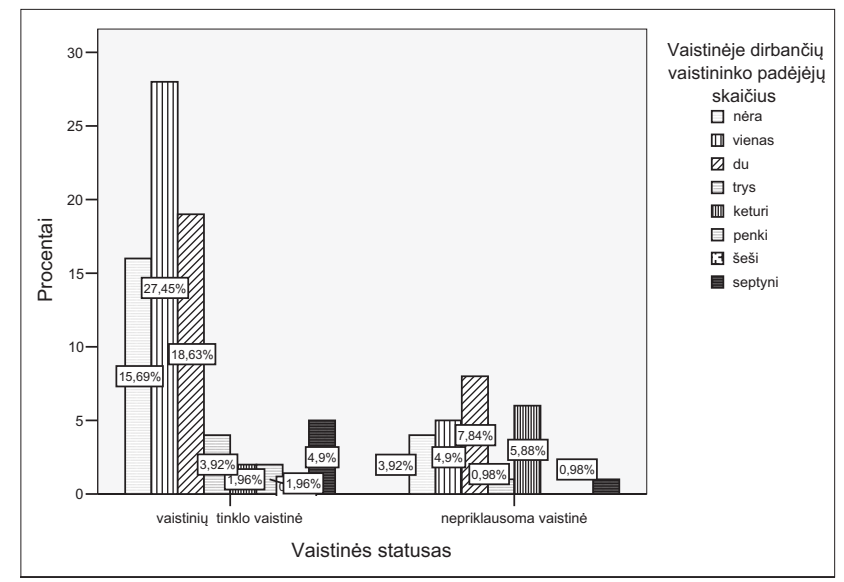

2 pav. Vaistininko padėjējų (farmakotecnikų) skaičius (vnt.) penkių etnografinių regionų vaistinèse $\left(\chi^{2}-14,415\right.$, Ils $\left.-7, p-0,044\right)$ 


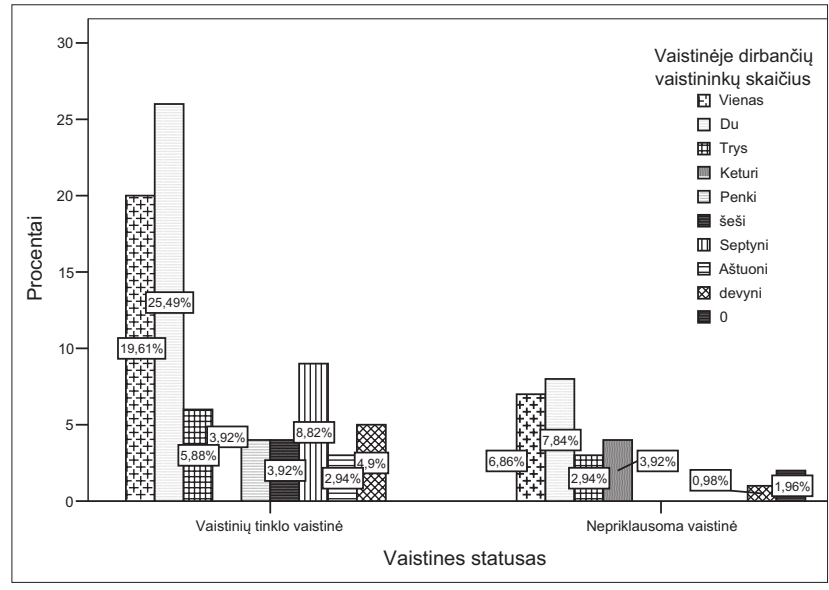

3 pav. Vaistininkų vidutinis skaičius (vnt.) penkių etnografinių regionų vaistinėse ( $\left(\chi^{2}-25,599,1 l s-9, p-0,002\right)$

Dažniausiai vaistinėje dirba vienas (32,4\%), du (26,5\%) vaistininko padèjëjai (farmakotechnikai) arba jų vaistinèje nèra $(19,6 \%)$ (3 pav.).

Dažniausiai vaistineje dirba du $(33,3 \%)$ arba vienas (26,5\%) vaistininkas (4 pav.).

Ištyrus gyventojų, perkančių vaistinejje receptinius ir nereceptinius vaistus bei vaistinių prekes, nustatyta, kad nepriklausomose vaistinèse gyventojai pirko receptiniu vaistų $36 \%$, nereceptinių vaistų - 29,5\%, ekstemporalių vaistų- 4,4\%, vaistinių prekių - 29,7\% . Vaistinių tinklų vaistinėse gyventojai pirko receptinių vaistų $28 \%$, nereceptinių vaistų $-25,5 \%$ ir daugiausia (45\%) vaistinių prekių.

\section{IŠVADOS}

1. 2011 - 2012 metais Lietuvos penkių etnografinių regionų (Aukštaitijos, Žemaitijos, Dzūkijos, Suvalkijos, Mažosios Lietuvos) tirtos 102 visuomenès vaistinès, kurios yra strategiškai palankiose vaistų pardavimui gyventojams lankomose vietose.

2. $40 \%$ visuomenès vaistinių dirba tik vienas vaistininko padejjëjas (farmakotechnikas), o 21,6\% visuomenès vaistinių - nèra vaistininko padèjèjo (farmakotechniko). Gerinant farmacinès paslaugos gyventojams kokybę, racionalu didinti vaistininko padejejeju (farmakotechnikų) etatų skaičių visuomenès vaistinèse.

3. Nepriklausomose vaistinėse gyventojai perka receptinių vaistu $36 \%$, nereceptinių - 29,5\%, ekstemporalių - 4,4\%, vaistinių prekiu - 29,7\% . Vaistiniu tinklų vaistinėse gyventojai perka receptinių vaistų $28 \%$, nereceptiniu $-25,5 \%$ ir daugiausia $(45 \%)$ vaistinių prekių.

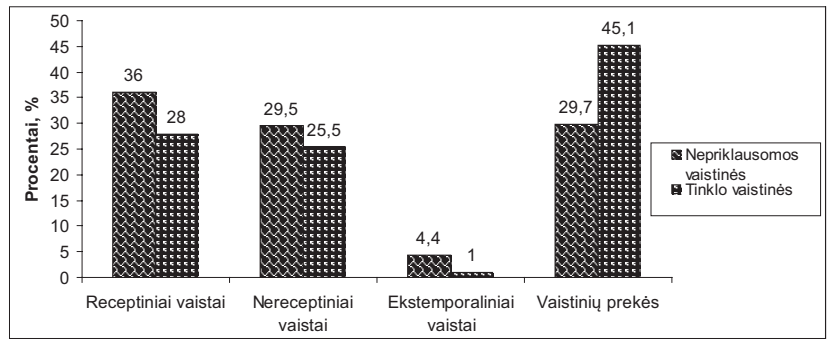

4 pav. Receptinių ir nereceptinių vaistų bei vaistinių prekių pardavimų kiekis penkiuose etnografiniuose regionuose procentais.

Literatūra

1. Galminienė G., Balsienè J. Vaistinių veiklos teisinis reglamentavimas Lietuvoje racionalaus vaistinių preparatų vartojimo aspektu. Socialinių mokslų studijos, 2011; 3(1):293-307.

2. Lietuvos Rspublikos seimas.Lietuvos respublikos farmacijos įstatymo $2,4,5,7,35,39,76$ straipsnių pakeitimo ir papildymo ịstatymas XI2017. Valstybès žinios, 2012-06-05; 63:3161.

3. Skyrius V. Farmacinè rūpyba vaistininko praktikoje. Farmacija ir laikas, 2006; 1:89.

4. Lietuvos Respublikos sveikatos apsaugos ministro įsakymas dèl geros vaistinių praktikos nuostatų patvirtinimo, $2007 \mathrm{~m}$. birželio $15 \mathrm{~d}$. Nr. V-494. Vilnius. Valstybės žinios, 2007; 68:2690.

5. Urbonas G., Jakušovaitė I., Savickas A. Farmacijos specialistu požiūris ị farmacinès paslaugos kokybę visuomenès vaistinèse. Medicina (Kaunas), 2010; 46 (10):686-692.

6. Babonienė E., Jonaitienė L., Ragažinskienė O., Motinė R. Nuolatinis vaistininkų padèjèjų mokymasis - vienas iš vaistinèje teikiamos farmacinès paslaugos vystymosi veiksnių Lietuvoje. Tarptautinès konferencijos „Šiuolaikinio specialisto kompetencijos: teorijos ir praktikos dermé“ medžiaga, 2010, Kaunas.

7. Daukšienė J., Radžiūnas R. Vaistinès pacientu nesilaikymas nurodymų vartojant vaistus ir jų požiūris ị namų vaistinėlèje esančius vaistus. Medicina (Kaunas), 2009; 45(12):1013-1018.

8. Grincevičius J., Radžiūnas R. Nuolatinio mokymosi ypatumai: farmacijos specialistų ižvalgos profesinès kvalifikacijos atžvilgiu. Prieiga per internetą http://www.biblioteka.vpu.lt/pedagogika/PDF/2007/86/105110.pdf.

9. Babonienė E., Ragažinskienė O., Mickienė Ž., Jonaitienė L. Farmacinès paslaugos kaitos galimybės pagal farmacinès rūpybos rekomendacijas. Sveikatos mokslai, 2010; 3(20):3186 - 3190.

10. Zweber A, Roche VF, Assemi M, Conry JM, Shane-McWhorter L, Sorensen TD. Curriculum recommendations of the AACP-PSSC task force on caring for the underserved. Am J Pharm Educ. USA, 2008; 72(3):53.

11. Henri R. Manasse, Jr., Marilyn K. Speedie ,Pharmaceuticals and Policy Issues Shaping the Work Force in Pharmacy: The Work-force Continuum: Pharmacy Technicians,Pharmacists, Specialization, and Postgraduate Training. Am J Health Syst Pharm, 2007; 64(12):e30-e48.

12. Franklin R. Pharmacists Taking a More Active Role in Patient Care An Expert Interview With Douglas Scheckelhoff, MS, RPh, FASHP, Medscape Medical News, June 24, 2011. Prieiga per internetą [http:// www.medscape.com/viewarticle/745268].

13. Need for Uniform National Standards for the Education and Training of Pharmacy Technicians

Posted: 06/03/2004; American Journal of Health-System Pharmacy, 2004;61(11) C 2004 American Society of Health-System Pharmacists. Prieiga per internetą [http://www.medscape.com/viewarticle/479511].

14. Governance and the Pharmaceutical Workforce in England Pe- 
ter Noyce, PhD. Medscape Pharmacists,2006;8(2). Prieiga per internetą [http://www.medscape.com/viewarticle/546468].

15. Babonienė E., Jonaitienè L., Ragažinskienė O. Peculiarities of the professional education and qualification appraisal of assistants of pharmacists in Lithuania, 8 oji Tarptautinè farmacijos mokslų konferencija, Oporto institutas, Portugalija, 2012.

http://issuu.com/profangelojesus/docs/proceedings 8thpharmacycon ference ? mode $=$ window\&backgroundColor $=\% 23222222$

16. Farmacijos ịmonès ir specialistai (skaičiai) - 2011-12-31. Prieiga per internetą [http://www.vvkt.lt/index.php?182821045].

CONTEMPORARY CONDITION OF THE PHARMACEUTICAL SERVICE PROVIDED BY ASSISTANTS OF PHARMACISTS IN COMMUNITY PHARMACIES IN LITHUANIA

Edita Baboniené, Laimute Jonaitienè, Ona Ragažinskienè

Summary

Key words: pharmacist, assistants of pharmacists, pharmaceutical service, prescription medication, non-prescription medication, pharmaceutical goods, Lithuania.

The article presents contemporary condition of the pharmaceutical service provided by the assistant of pharmacist in the community pharmacies in five ethnographic regions of Lithuania. In the year 2012 the research was carried out in 102 community pharmacies from Aukštaitija, Žemaitija, Dzūkija, Suvalkija and Lithuania Minor that were situated in the places strategically favorable for the sale of medication.

$40 \%$ of community pharmacies employ only one assistant of pharmacist (pharmacy technician), while 21,6\% of community pharmacies do not employ any assistants of pharmacist (pharmacy technicians). In order to improve the quality of the pharmaceutical service for people it is rational to increase the number of assistants of pharmacists (pharmacy technicians) in the community pharmacies.

In the community pharmacies that do not belong to any pharmacy networks people buy $36 \%$ of prescription medication, $29,5 \%$ of non-prescription medication, 4,4\% of extemporal medication, 29,7\% of pharmacy goods. In the pharmacies that are part of some pharmaceutical network people tend to buy $28 \%$ of prescription medications, 25,5\% of non-prescription medications and most of all (45\%) pharmacy goods.

The aim of the research: to analyze the pharmaceutical service provided by assistants of pharmacist (pharmacy technicians) in the sales of medication and pharmacy goods by identifying the frequency of their dispensing depending on the status of pharmacies. The research revealed that while providing pharmaceutical service the positive influence on the process would be made by the increase in the number of the assistants of pharmacist (pharmacy technicians) employed in the pharmacy. The major part of the sales turnover of medication and pharmacy goods is constituted by different pharmacy goods while the rest of the turnover comprises prescription and non-prescription medication. The direction of the pharmaceutical service provided by assistants of pharmacist (pharmacy technicians) towards the sales of pharmacy goods would enable the pharmacists to give more time for the consultations of customers and the advisory activities in the area of health improvement.

Correspondence to: laimutejntn7@gmail.com

Gauta 2012-09-06 